\title{
Differential Induction of Apoptosis in Oncogene-Transformed NIH 3T3 Cells by Methylmethanesulfonate
}

\author{
Min-Liang Kuo, ${ }^{*} \dagger$ Yi-Wen Chou, ${ }^{*}$ Yat-Pang Chau $\ddagger$ and Tzu-Ching Meng* \\ *Institute of Toxicology, College of Medicine, National Taiwan University, Taipei, Taiwan; And \\ fInstitute of Anatomy, School of Life Science, National Yang-Ming University, Taipei, Taiwan
}

\begin{abstract}
Cellular oncogenes have been shown to play crucial roles in the cell death process induced by cytotoxic agents. In this study, we have demonstrated that v-H-ras transformed NIH 3T3 cells but not other transformants ( $\mathrm{v}$-raf, v-src, v-erbB-2, v-fes and v-mos) exhibited a survival advantage to treatment by a DNAdamaging agent, methylmethanesulfonate (MMS). Subsequently, the biochemical and morphologic criteria of MMS-treated cells were examined. It was found that MMS induced v-H-ras transformants to go through necrosis, but it induced other transformed cells to undergo apoptosis. The levels of glutathione (GSH) within each transformant: as well as in NIH 3T3 cells, were determined. The results showed that GSH levels within ras transformants were 2- to 7-fold higher than the levels in other transformants and normal NIH 3T3 cells. By using the GSH synthesis inhibitor buthionine sulfoximine, GSH levels were artificially reduced. This depletion, however, made ras transformed cells more sensitive to MMS killing, but the mode of cell death was still necrosis. Western blot analysis demonstrated that the anti-apoptotic protein $\mathrm{Bcl}-2$ was constitutively expressed in ras transformed cells but not in NIH 3T3 or other transformed cells. The level of Bcl-2 was correlated with the resistant phenotype of ras transformants during MMS treatment. These observations suggest that GSH and Bcl-2 levels may cooperatively confer the resistant phenotype of ras transformants in response to MMS. In addition, the mode of cell death may possibly be determined at least in part by $\mathrm{Bcl}-2$ protein. BIOCHEM PHARMACOL $52 ; 3: 481-48 \varepsilon, 1996$.
\end{abstract}

KEY WORDS. apoptosis; necrosis; glutathione; Bcl-2 protein; NIH 3T3 cells; ras-transformed NIH 3 T3 cells

The process of cell death can be classified typically into two types: apoptosis and necrosis. Apoptosis differs from necrosis in that its early stages show chromatin condensation and DNA fragmentation; in addition, cytoplasmic organelles remain intact [1]. The dying cells fragment into small, membrane-enclosed apoptotic bodies, which are taken up rapidly by resident phagocytic cells. The process of apoptosis often depends on RNA and protein syntheses in the dying cells, indicating positive participation of cells in the death processes [2]. In contrast, necrotic cells undergo rapid cytoplasmic swelling with gross disruption of organelle function prior to cell lysis [1]. Numerous cancer cells have been reported to undergo apoptosis when treated with antitumor agents such as etcposide (VP-16), camptothecin, cisplatin, and vincristine [3-6].

Some specific oncogene; and oncosuppressors may play

\footnotetext{
† Corresponding author: Dr. Min-Liang Kuo, Institute of Toxicology, College of Medicine, National Taiwan University, No. 1, Section 1, Jen-Ai Road, Taipei, Taiwan. FAX (011) 886-2-341-0217.

\$ Abbreviations: MAPK, mitogen-activated protein kinase; MAPKK, MAPK kinase; MEK, (MAP kinase or erk) kinase; MMS, methylmethanesulfonate; GSH glutathione; and BSO, buthionine sulfoximine.

Received 5 December 1995; accepted 19 February 1996.
}

crucial roles in the regulation of cell proliferation and apoptosis. For example, NIH 3T3 cells transfected with and overexpressing $\mathrm{c}-\mathrm{H}$-ras genes became more resistant to anticancer drugs including cisplatin, Adriamycin ${ }^{\circledR}$, melphalan, and CPT - 11 [7]. Also, Burt et al. [8] demonstrated that both v-H-ras and v-raf oncogenes could transform rat liver epithelial cells, resulting in an increase of cellular resistance to treatment with genotoxic agents such as Adriamycin, vinblastine, and 2-acetylaminofluorene. Generally, this drug resistance is accompanied by an elevated expression of P-glycoprotein and glutathione-S-transferase P [8]. The suppression of endogenous $\mathrm{H}$-ras function by a dominant negative $\mathrm{v}$-H-ras mutant resulted in apoptosis of $\mathrm{K} 562$ leukemia cells [9]. This directly indicates that ras itself or the ras-associated pathway may have the ability to suppress some apoptosis induced by exogenous stimuli. However, the precise mechanism(s) by which ras oncogenes provide a survival advantage to cells remains unclear.

It is noteworthy that a core signaling unit has been identified recently, consisting of Ras-Raf and Raf-regulated kinases such as MAPKK/MEK-MAPK§, which integrates signals originating from protein tyrosine kinases and protein kinase $C$ at the membrane [10-12]. This signaling pathway has been thought to play a role in both mitogenic and 
transforming activities in various oncogene-transformed cells, like ras, raf, mos and fes [13-15]. Based on these observations, a question is raised as to whether oncogenes, which have been suggested to associate with the core signaling transduction pathway, are related to the mechanism of resistance to toxic agent-induced cell death.

Therefore, in the present study we employed several viral oncogene-transformed NIH 3 T3 cell lines, including $v-H$ ras, v-raf-1, v-src, v-fes, v-erbB-2 and v-mos, to examine the response to cell death following exposure to MMS, a DNAdamaging agent. We further demonstrated that GSH levels determine the capacity of drug resistance but not the mode of cell death in these cell lines. Finally, Bcl-2 protein was found to be elevated in v-H-ras transformed cells but not in normal or other oncogene-transformed cells, suggesting that $\mathrm{Bcl}-2$ may play a role in the prevention of MMS. induced apoptosis.

\section{MATERIALS AND METHODS Cells and Culture}

$\mathrm{v}$-Ha-ras, v-raf, v-src, v-mos, v-erbB-2 and v-fes transformed NIH 3T3 cells were obtained from Dr. S-F. Yang of the Institute of Molecular Biology, Academia Sinica, Taipei, Taiwan. The v-Ha-ras transformed cells were grown in Dulbecco's modified Eagle's medium supplemented with $10 \%$ calf serum, $2 \mathrm{mM}$ L-glutamine, G418 (100 $\mu \mathrm{g} / \mathrm{mL})$, and antibiotics. Other oncogene-transformed and parental $\mathrm{NIH} 3 \mathrm{~T} 3$ cells were cultured in the same medium without G418.

\section{Drug Treatment and Cell Viability}

Cells were incubated with $1 \mathrm{mM}$ MMS (Aldrich Co., Milwaukee, WI, U.S.A.) for varying time periods, as indicated in Fig. 1. After incubation, the cells were washed twice in ice-cold PBS, and cell viability was determined using the trypan blue exclusion assay.

\section{DNA Extraction and Electrophoresis}

After different treatments, both attached and floating cells were harvested, washed in ice-cold PBS, resuspended in 500 $\mu \mathrm{L}$ of TE (10 mM Tris-HCl $\mathrm{pH} 7.6,1 \mathrm{mM}$ EDTA, $\mathrm{pH} 8.0)$, and lysed in $500 \mu \mathrm{L}$ of lysis buffer ( $3 \%$ SDS, $50 \mathrm{mM}$ Tris, $\mathrm{pH} 12.6)$ at room temperature for $10 \mathrm{~min}$. DNA was extracted with phenol and chloroform before ethanol precipitation. DNA pellets were finally solubilized in TE buffer, and treated with RNase $A$ for 40 min prior to $1.2 \%$ agarose gel electrophoresis.

\section{Flow Cytometry Analysis}

At specific time points, treated or untreated cells were trypsinized and fixed in $75 \%$ ethanol at $-20^{\circ}$ for at least $1 \mathrm{hr}$. After centrifugation at $2000 \mathrm{~g}$ for $5 \mathrm{~min}$ at $4^{\circ}$, cell pellets were resuspended in $0.5 \mathrm{~mL}$ of a hypotonic buffer $(0.5 \%$
Triton X-100/PBS and $0.05 \%$ RNase A) and incubated for $30 \mathrm{~min} ; 0.5 \mathrm{~mL}$ of propidium iodide solution $(50 \mu \mathrm{g} / \mathrm{mL})$ was added and the pellets were allowed to stand on ice for 15-30 min. Fluorescence emitted from the propidium iodide-DNA complex was quantitated after laser excitation of the fluorescent dye by a FACSort flow cytometer (Becton-Dickinson, San Jose, CA, U.S.A.).

\section{Electron Microscopy}

Cells were fixed with $2 \%$ glutaraldehyde and $2 \%$ paraformaldehyde in PBS for $15 \mathrm{~min}$. Following several rinses in PBS, cells were postfixed in $1 \%$ osmium tetroxide, dehydrated in alcohol, and embedded in an Epon-Araldite mixture. Thin sections were cut and doubly stained with uranyl acetate and lead citrate before being examined in a Joel 2000 EXII electron microscopy at $100 \mathrm{kV}$.

\section{Determination of Total Intracellular GSH Level}

About $10^{7}$ cells were harvested by scraping off the bottom of the dish with a rubber policeman. Cell pellets were washed with ice-cold PBS, resuspended in $300 \mu \mathrm{L}$ of $\mathrm{A}$ buffer (125 mM KH ${ }_{2} \mathrm{PO}_{4}, 6.3 \mathrm{mM}$ EDTA; $\mathrm{pH} 7.5$ ), subjected to rapid freeze-thaw lysis four times, and reacted in a sonicator (Branson, 2200) for $5 \mathrm{~min}$. The supernatant that was obtained by centrifugation at $2000 \mathrm{~g}$ for $5 \mathrm{~min}$ was divided into two parts: $50 \mu \mathrm{L}$ and $250 \mu \mathrm{L}$. The cellular protein content in the $50 \mu \mathrm{L}$ of supernatant was determined using the Bio-Rad protein assay. The GSH level was measured in the remaining $250 \mu \mathrm{L}$ to which $100 \mu \mathrm{L}$ of $12 \%$ 5-sulfosalicylic acid (Sigma, St. Louis, MO, U.S.A.) was added and then allowed to stand on ice for 2-3 hr to allow protein precipitation. Cellular protein was removed by centrifugation at $14,000 \mathrm{~g}$ for $15 \mathrm{~min}$, after which $200 \mu \mathrm{L}$ of supernatant was obtained. The NADPH reagent $(0.525$ $\mathrm{mM})$ and $5,5^{\prime}$-dithiobis-2-nitrobenzoic acid $(1.5 \mathrm{mM})$ were purchased from Sigma and prepared in B buffer $(187.5 \mathrm{mM}$ $\mathrm{KH}_{2} \mathrm{PO}_{4}, 6.3 \mathrm{mM}$ EDTA; $\mathrm{pH} 7.5$ ). GSH was measured by the method of Nakagawa et al. [16], utilizing an enzymatic recycling assay based on GSH reductase. To measure the GSH, $400 \mu \mathrm{L}$ of 5,5'-dithiobis-2-nitrobenzoic acid, $400 \mu \mathrm{L}$ of NADPH, $200 \mu \mathrm{L}$ of supernatant, and $3 \mu \mathrm{L}$ of GSH reductase were added serially in a $10 \times 45 \times 4 \mathrm{~mm}$ plastic cuvette. The absorbance of the mixture at $412 \mathrm{~nm}$ was monitored on a Hitachi (U-3210) recording spectrophotometer and recorded at $20-\mathrm{sec}$ intervals for $3 \mathrm{~min}$. Results represent the means \pm SEM of values from three separate experiments.

\section{Western Blotting}

Cellular lysates were prepared as described by Kuo and Yang [17]. A 50- $\mu$ g sample of each lysate was subjected to electrophoresis on $15 \%$ SDS-polyacrylamide gels for detection of $\mathrm{Bcl}-2 \mathrm{p} 26$. The samples were then electroblotted on nitrocellulose paper. After blocking, blots were incubated 


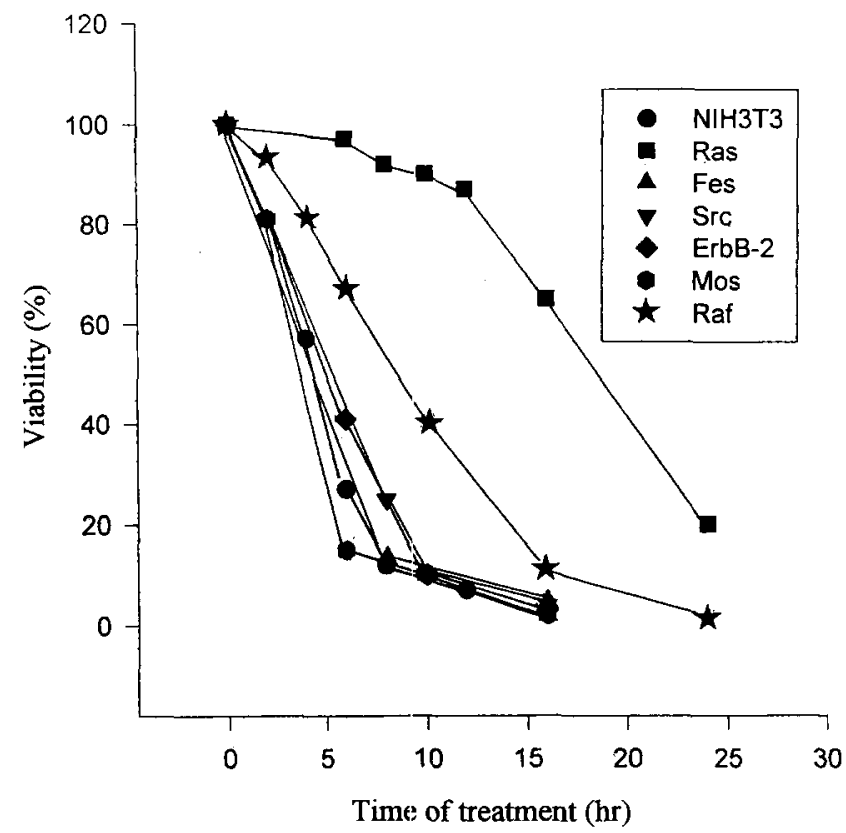

FIG. 1. Sensitivity of oncogrene-transformed and parental NIH 3 T 3 cells to MMS killing. Cells were plated in a density of $1 \times 10^{6}$ cells $/ 100 \mathrm{~mm}$ dish in the presence of $1 \mathrm{mM}$ MMS for different time periods. Viable cells were measured by a trypan blue exclusion assay. Each point represents the mean value of duplicate experiments.

with anti-Bcl-2 (Santa Cruz Biotechnology, Inc., Santa Cruz, CA, U.S.A.) antibody in PBST (PBS-0.1\% Tween 20) for $1 \mathrm{hr}$ followed by two washes (15 min each) in PBST, and then incubated with horseradish peroxidase-conjugated goat anti-mouse IgG (Amersham, Arlington Heights, IL, U.S.A.) for $30 \mathrm{~min}$. After washing, the blots were incu- bated for $1 \mathrm{~min}$ with western blotting reagent ECL (Amersham), and chemiluminescence was detected by exposure of the filters to Kodak X-Omat films for $10 \mathrm{sec}$ to $10 \mathrm{~min}$.

\section{RESULTS}

The resistance of transformed cell lines and normal NIH 3T3 cells to MMS-mediated cytotoxicity was determined by trypan blue exclusion. These cell survival curves (Fig. 1) revealed a survival advantage for $\mathrm{v}-\mathrm{H}$-ras and $\mathrm{v}$-raf transformed cells relative to other transformed cells and normal NIH 3T3 cells when exposed to $1 \mathrm{mM}$ MMS for various time periods. Furthermore, the ras transformed cells were more resistant than the raf transformants to MMS killing.

The mode of cell death induced by MMS in these cells was determined via assaying DNA fragmentation, apoptotic peak, and nuclear chromatin condensation, respectively. As shown in Fig. 2A, NIH 3 T3 cells treated with $1 \mathrm{mM}$ MMS showed typical patterns of internucleosomal DNA laddering within $8-16 \mathrm{hr}$, but smearing at $24 \mathrm{hr}$. The same pattern of internucleosomal DNA ladder was also evident in the oncogene-transformed cells v-src, v-raf, v-erbB-2, $v$-mos and $v$-fes by $10 \mathrm{hr}$ of treatment with MMS (Fig. 2B). In contrast, $v$-Ha-ras transformed cells retained an intact genomic DNA pattern after treatment with $1 \mathrm{mMMMS}$ for $10 \mathrm{hr}$ (Fig. 2C, lane 3). Even when $80 \%$ of the ras transformants were killed by exposure to MMS for $24 \mathrm{hr}$, the pattern of genomic DNA appeared as a slight smearing rather than laddering (Fig. 2C, lane 6).

Another method of assessment of apoptosis was based on the assay of DNA strand breaks in individual cells by flow cytometry. Generally, the results obtained by this method

A

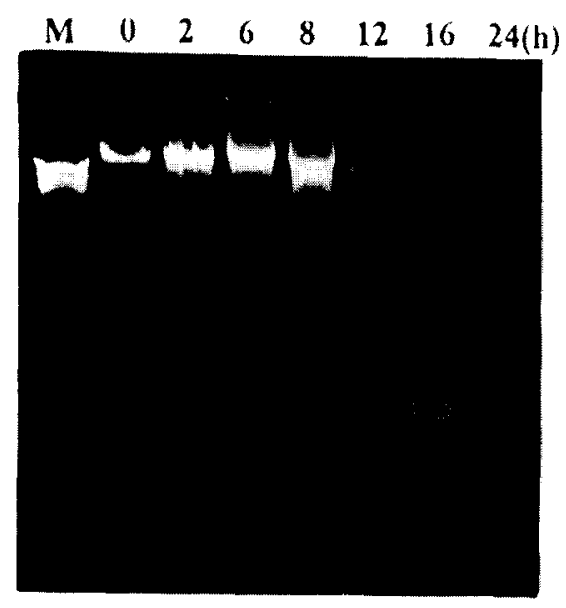

$\mathrm{B}$
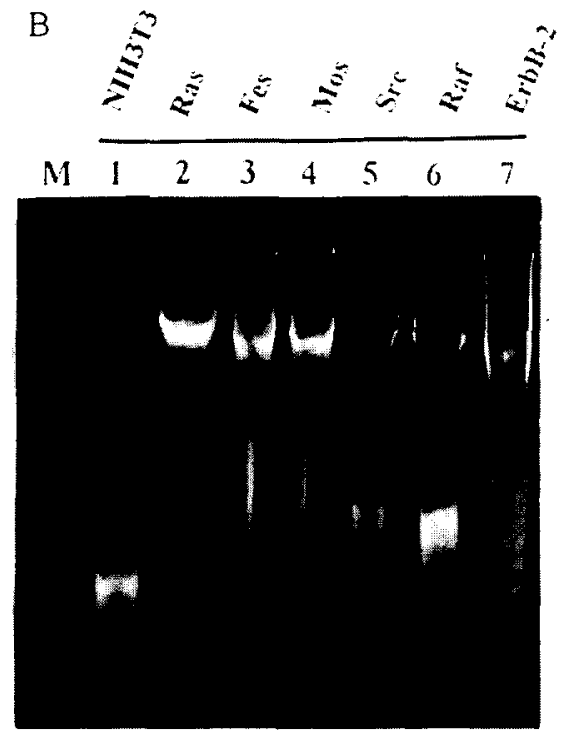

C

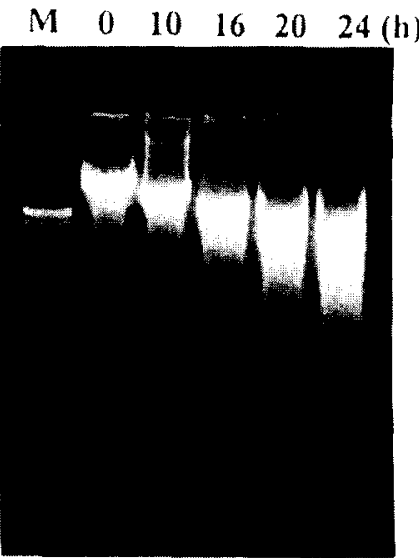

FIG. 2. Internucleosomal DNA fragmentation in various oncogene-transformed and parental NIH 3T3 cells treated with MMS. (A) NIH 3 T3 cells were exposed to $1 \mathrm{mM}$ MMS for different periods of time as indicated in the figure; (B) different oncogene-transformed cells were treated with $1 \mathrm{mMMMS}$ for $10 \mathrm{hr}$; (C) ras transformed NIH 3T3 cells were exposed to $1 \mathrm{mM}$ for 0-24 hr. DNA from different treatment protocols was extracted and electrophoresed through $1.2 \%$ agarose gel. DNA bands were visualized by staining with ethidium bromide. 

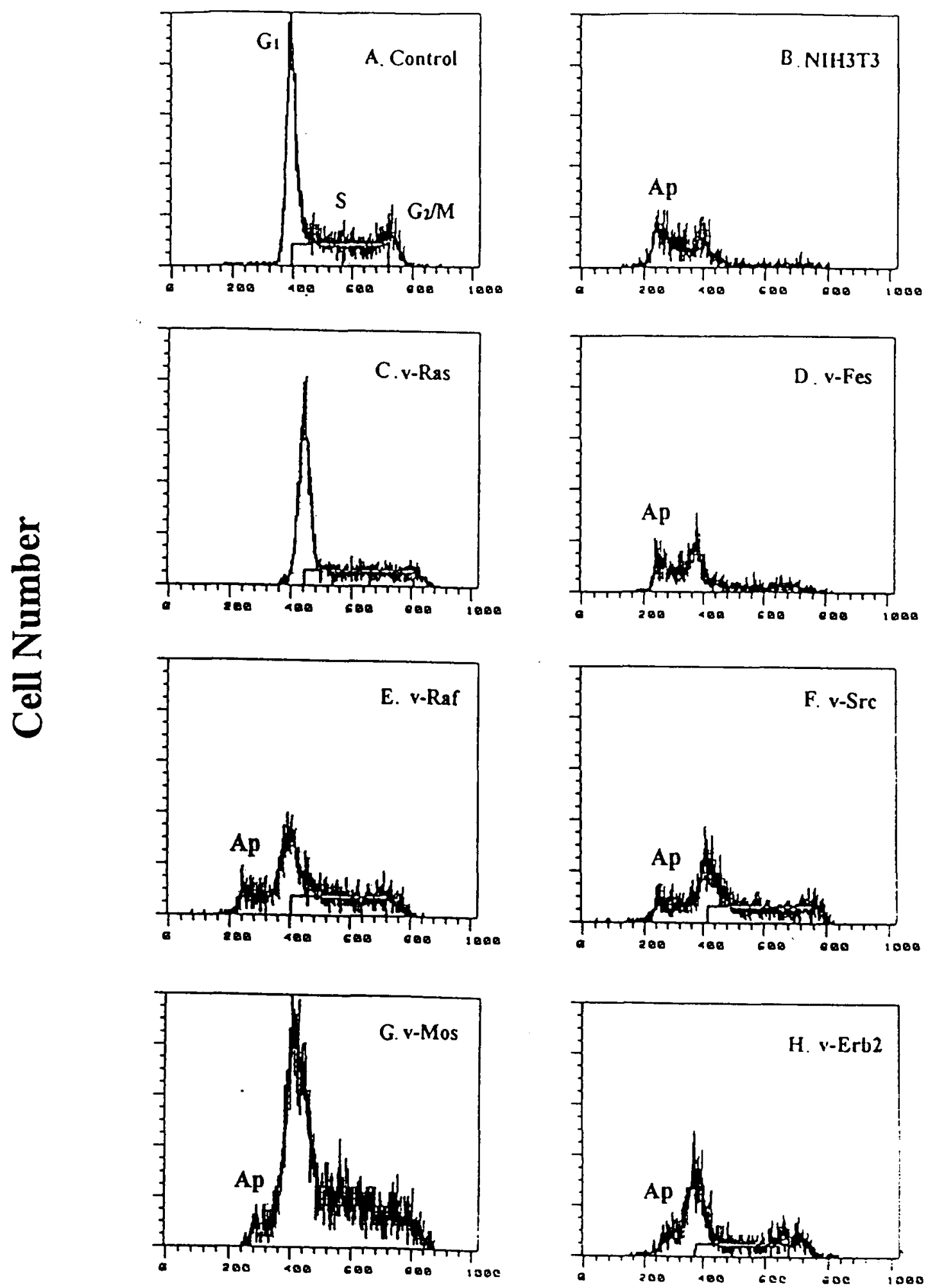

\section{PI-DNA fluorescence}

FIG. 3. Cell cycle analysis of oncogene-transformed and normal NIH 3T3 cells following treatment with MMS. Various oncogene-transformed and their parental NIH 3T3 cells were cultured in the presence or absence of $1 \mathrm{mM}$ MMS for $12 \mathrm{hr}$. After removal of MMS, cells were fixed and stained with propidium iodide (PI) as described in Materials and Methods, and the DNA content was analyzed by flow cytometry. Ap represents the peak of apoptotic bodies. 

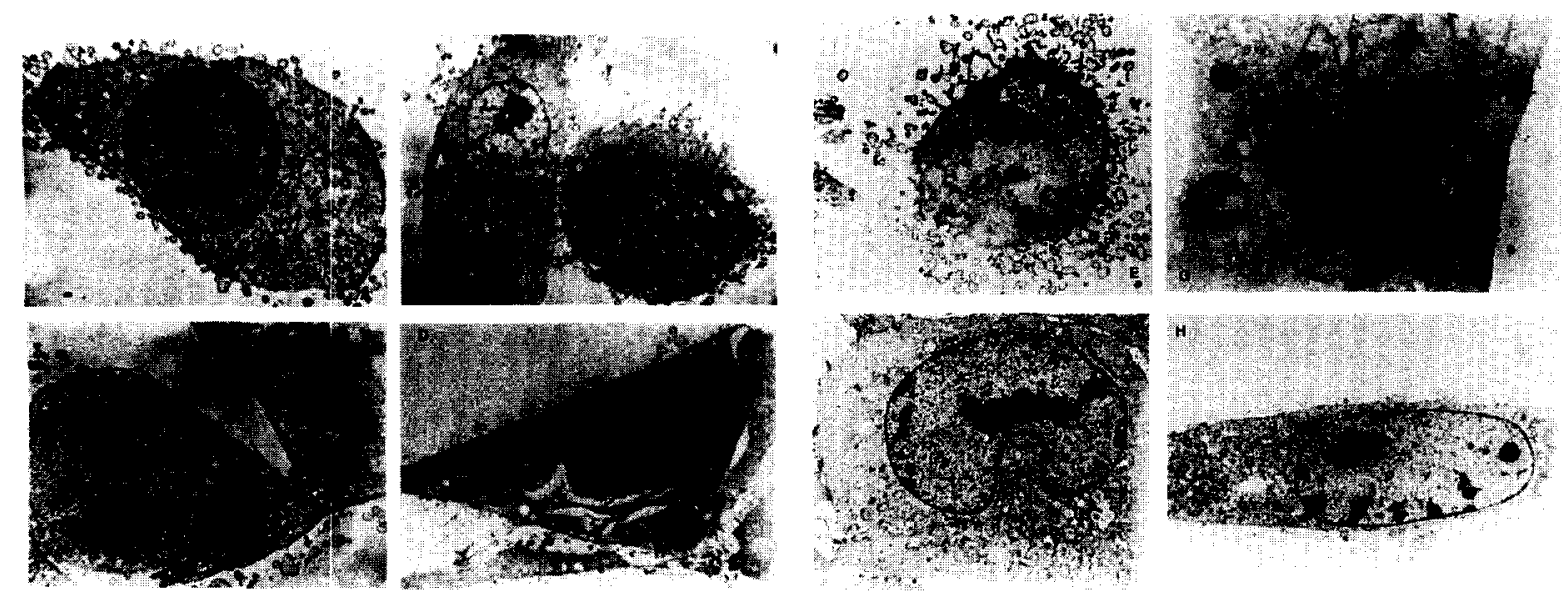

FIG. 4. Morphology of apoptosis occurring in various oncogene-transformed and normal NIH 3 T3 cells following treatment with MMS. (A) Control untreated NIH 3T3 cells, (B) NIH 3 T3 cells, (C) ras transformants, (D) fes transformants, (E) mos transformants, (F) raf transformants, (G) src transformants, and (H) erbB-2 transformants were exposed to MMS for $10 \mathrm{hr}$. After removal of MMS, cells were fixed and examined as described in Materials and Methods. Original magnification: $\times 600$.

were in agreement with the data based on the DNA laddering, analyzed on agarose gel electrophoresis. Transformed cells such as v-fes, v-raf, v-src, v-mos, v-erbB-2 (Fig. $3, \mathrm{D}-\mathrm{H}$ ) and normal NIH $3 \mathrm{~T} 3$ cells (Fig. 3B) were found to show a typical sub- $\mathrm{G}_{1}$ peak (apoptotic peak, Ap) at $12 \mathrm{hr}$ of MMS treatment. However, the sub- $\mathrm{G}_{1}$ peak was not observed in MMS-treated v-H-ras transformed cells (Fig. 3C).

Consistent with the results obtained from DNA fragmentation and flow cytometry, cell morphology examined by electron microscopy demonstrated that MMS-treated $\mathrm{v}-\mathrm{H}$ ras transformed cells did not show any morphological changes (Fig. 4C) when compared with untreated cells (Fig. 4A). Under the same treatment, the morphological features

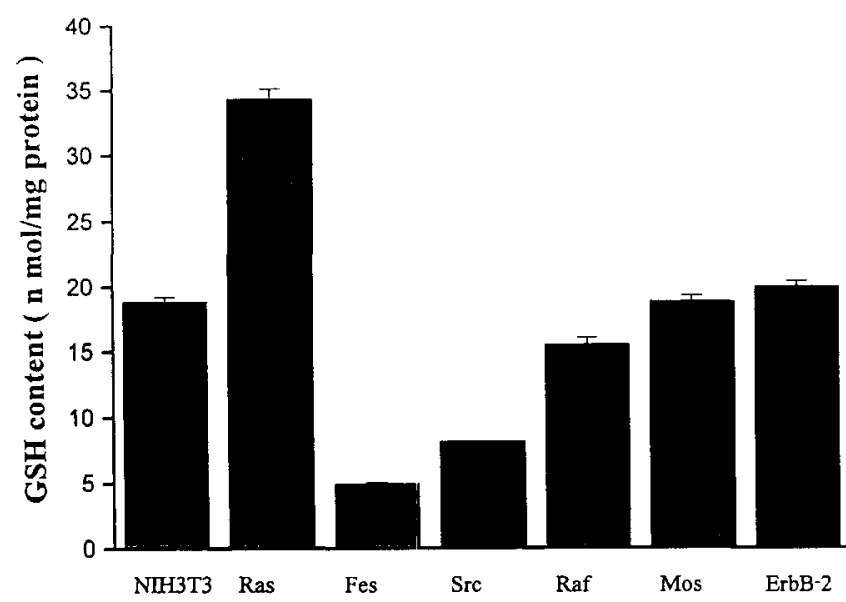

FIG. 5. Determination of GSH content within oncogenetransformed and normal NIFI 3 T 3 cells. Cells $\left(1 \times 10^{7}\right)$ were harvested and washed with ice-cold PBS, and then were lysed by rapid freeze-thaw. The supernatant was obtained by centrifugation, and further means were used to measure the content of GSH. The detailed procedure is described in Materials and Methods. Values are the means \pm SEM obtained from at least three separate experiments for each cell line. of apoptosis, including compaction and segregation of nuclear chromatin, discreteness of nucleus and cytoplasm as well as blebbing of cell membrane, were evident in other transformed (Fig. 4, D-H) and normal NIH 3T3 cells (Fig. 4B).

Based on these observations, we suggest that activated ras gene but not other oncogenes abrogates the apoptotic cell death induced by the DNA-damaging agent MMS. Although other oncogenes have been found to associate directly or indirectly with the RAS-RAF-MEK-MAPK signaling transduction pathway, they still undergo apoptosis upon MMS treatment. To determine the possible mechanism by which ras transformed cells can increase resistance to MMS-induced apoptosis, we first examined the levels of GSH within each transformant and normal NIH 3T3 cells. The results demonstrated that the amount of GSH in the $\mathrm{v}$-Ha-ras transformant was 2-to 7-fold higher than that of other oncogene-transformed cells and NIH 3T3 cells (Fig. 5). $\mathrm{BSO}$ an irreversible inhibitor of $\boldsymbol{\gamma}$-glutamylcysteine synthetase, was used to reduce the GSH levels in ras transformed cells. After a 16-hr incubation with $50 \mu \mathrm{M}$ BSO, GSH in ras transformed cells could be reduced to a level similar to that of the parental NIH 3T3 cells. However, the depletion of GSH by BSO did not produce any cytotoxic effect in the ras transformants (data not shown). Furthermore, we found that GSH-depleted ras transformed cells became more susceptible to MMS treatment (Fig. 6A), but the cells were induced to go through necrosis rather than apoptosis, as determined by agarose gel electrophoresis (Fig. 6B).

The bcl-2 gene, first identified by its deregulation in human follicular lymphoma [18], is known to prevent apoptosis induced by many, but not all, experimental conditions $[19,20]$. Thus, we examined whether $b c l-2$ is expressed in $\mathrm{v}$-H-ras transformed cells. Western blot analysis shows that bcl-2 protein was moderately expressed in ras transformed cells but not in NIH 3T3 cells (Fig. 7) or other transformed cells (data not shown). In addition, the level of Bcl-2 pro- 
$\mathbf{A}$

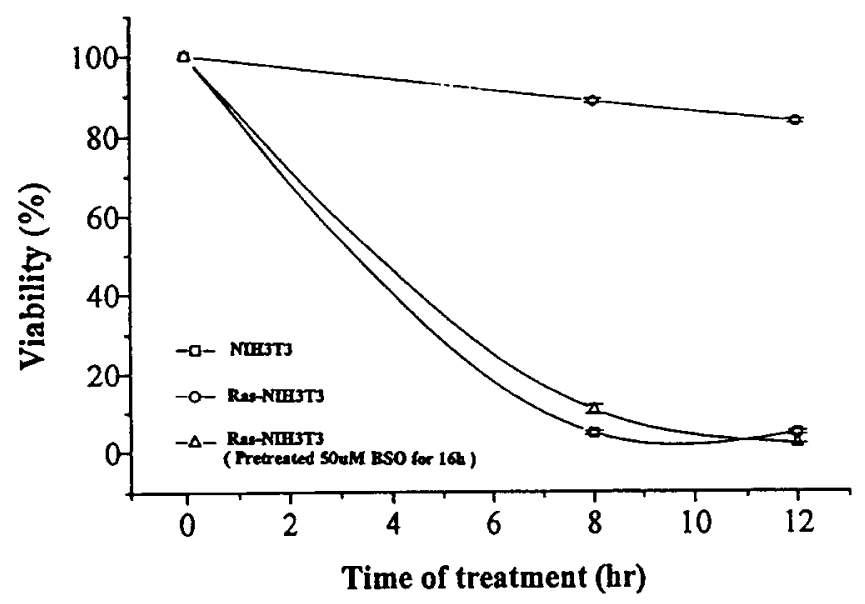

B

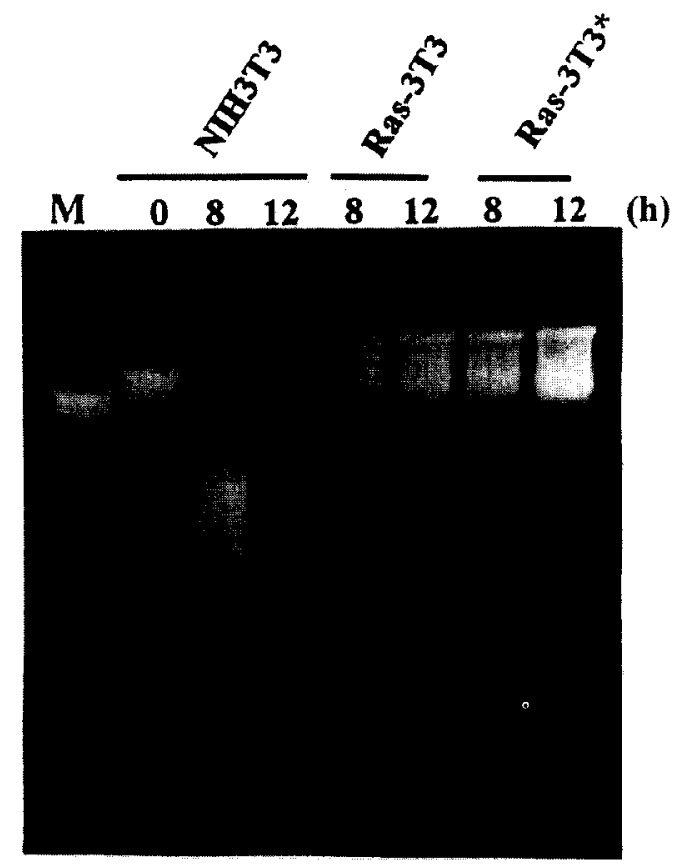

FIG. 6. Effects of GSH depletion on the resistant phenotype of ras transformants. (A) Increment of susceptibility of ras transformants to MMS-induced cell death by depletion of GSH. v-H-ras NIH 3 T3 cells were pretreated with BSO for $16 \mathrm{hr}$, and then exposed to $1 \mathrm{mM}$ MMS for various time periods. Viable cells were counted by means of the trypan blue exclusion assay. Values are the means \pm SEM obtained from three independent experiments. (B) Analysis of DNA fragmentation in GSH-depleted ras transformants following MMS treatment. v-H-ras transformed and its parental NIH 3T3 cells were exposed to $1 \mathrm{mM}$ MMS for various time periods as indicated. Ras-3T3* represents ras-transformed cells preincubated with BSO for $16 \mathrm{hr}$. The methods of DNA extraction and examination are described in detail in Materials and Methods.

teins in ras transformants remained unchanged during $10 \mathrm{hr}$ of MMS treatment, correlating with the resistant phenotype of ras transformants. The results presented here strongly indicate that $b c l-2$ may play an important role in determining the resistance and mode of cell death of ras transformants in response to MMS.

\section{DISCUSSION}

The results presented here clearly demonstrate that of the oncogene-transformed cells tested only the ras transformant exhibited a remarkable resistance to MMS-induced cell death. Constitutive activation of the MEK-MAPK signaling pathway has been reported to occur in all of the oncogene-transformed cells used here. It seems likely that the resistant characteristics acquired by the ras transformant may not relate to the core MEK-MAPK signal transduction pathway. Recently, Rodriguez-Viciana et al. [21] demonstrated that an important enzyme, phosphatidylinositol-3. $\mathrm{OH}$ kinase $(\mathrm{PI}(3) \mathrm{K})$, is a downstream target for $\mathrm{p} 21^{\text {ras }}$. The cellular targets of the products of PI(3)K are not defined clearly, although protein kinase $\mathrm{C}$ family members may be included [22]. Moreover, the two-hybrid system in yeast was used to screen a complementary DNA library for genes encoding Ras-binding proteins; four different genes, in addition to Raf, were detected [23]. Based on these observations, we suggest that some other signal transduction pathway(s) that uniquely exists in the ras transformant may be involved in such drug resistance.

GSH has been shown to play a critical role in cellular defense against a variety of injurious agents [24]. Also, several types of cancer cells have been found to increase their resistance to antineoplastic agents via elevating the GSH levels [25]. We demonstrated here that ras transformant displayed a 2- to 7-fold increase of GSH level as compared with other oncogene-transformed and normal cells; however, depletion of GSH made the ras transformant more susceptible to MMS killing. This led us to suggest that the resistant features of ras transformant to MMS should be determined mainly by the GSH content. These observations are consistent with those of earlier studies that showed an increase of GSH in various ras transformed cell lines [26]. GSH is synthesized by the consecutive actions of

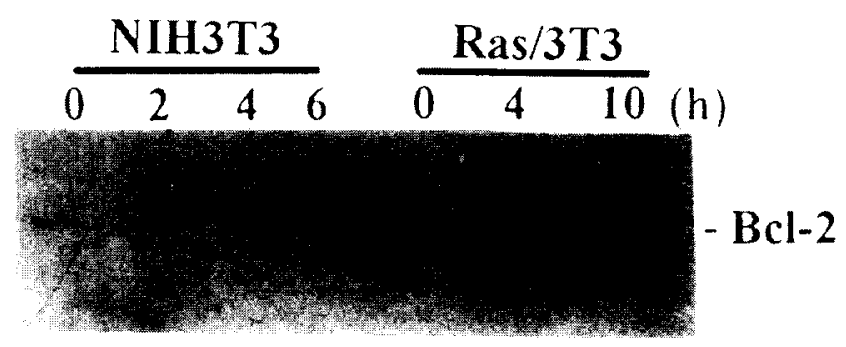

FIG. 7. Immunoblot analysis of $\mathrm{Bcl}-2$ in ras-transformed and normal NIH 3T3 cells. v-H-ras-transformed and its parental NIH 3T3 cells were exposed to $1 \mathrm{mM}$ MMS for various time periods as indicated in the figure. Cell lysates $(50 \mu \mathrm{g})$ were subjected to electrophoresis by SDS-PAGE and western blotted to nitrocellulose paper. The Bcl-2 was labeled by sequential incubation with monoclonal antibody to mouse Bcl-2 horseradish-conjugated goat anti-mouse IgG. Bound antibodies were detected by enhanced chemiluminescence. 
$\boldsymbol{\gamma}$-glutamylcysteine synthetase as well as GSH synthetase, and is utilized by several enzymes including the GSH transhydrogenase and GSH peroxidase. Which signal pathway in the ras transformant may participate in the alteration of the GSH pool remains elusive.

As demonstrated in the present study, MMS induced apoptosis in parental NIH 3'T3 and oncogene-transformed cells, including v-src, v-erbB-2, v-mos, v-fes and v-raf, but not in v-H-ras-transformed cells. The depletion of GSH made ras transformants become more sensitive to MMS. mediated necrotic cell death but not to apoptosis. This implies that some other cellular targets but not GSH regulate the mode of cell death of ras-transformed cells in response to MMS. It has been demonstrated that the overexpression of $b c l-2$ can prevent cell apoptosis induced by various injuries, including those caused by DNA damaging agents [27], growth factor withdrawal [19, 28], $\gamma$-irradiation, and a wide variety of chemotherapeutic drugs [27, 29]. The results presented here show that $\mathrm{Bcl}-2$ proteins were indeed expressed in the ras transformant but not in other transformants. Thus, we strongly suggest that the defect of apoptosis in the ras transformant is due, at least in part, to the expression of $b c l-2$. Corroborating our findings, it has heen demonstrated that activation of the ras pathway results in up-regulation of bcl-2 expression in 32D cells [30]. In addition, Fairbairn et al. [31] have shown recently that the overexpressed $b c l-2$ oncogene in murine hematopoietic cells results in the delay of MMS-mediated apoptotic cell death. We suggest that other possible mechanisms or molecules may also be included in regulating the apoptosis. For example, it is well documented that cells that harbor a wild-type p 53 will experience a $G_{1}$ arrest and subsequently undergo apoptosis upon treatment with a DNA-damaging agent. In contrast, mutant p53 enables cells to escape apoptosis $[32,33]$. Whether or not alteration of $\mathrm{p} 53$ occurs in the ras transformant is now under investigation.

This study was supported by the National Science Council, NSC 842331-B002-035, Taipei, Taiwan.

\section{References}

1. Wyllie AH, The biology of cell death in tumors. Anticancer Res 5: 131-142, 1985.

2. Martin SJ, Lennon SV, Bonham AM and Cotter TG, Induction of apoptosis in humar leukemia HL-60 cells by inhibition of RNA and protein synthesis. J Immunol 145: 18591863, 1990.

3. Barry MA, Reynolds JE ard Eastman A, Etoposide-induced apoptosis in human HL-60 cells is associated with intracellular acidification. Cancer Res 53: 2349-2357, 1993.

4. Evans DL and Dive C, Effects of cisplatin on the induction of apoptosis in proliferating hepatoma cells and nonproliferating immature thymocytes. Cancer Res 53: 2133-2139, 1993.

5. Barry MA, Behnke CA and Eastman A, Activation of programmed cell death (apoptosis) by cisplatin, other anticancer drugs, toxins and hyperthermia. Biochem Pharmacol 40: 2353 2362, 1990.

6. Eastman A, Activation of programmed cell death by anticancer agents: Cisplatin as a model system. Cancer Cells (Cold Spring Harbor) 2: 275-280. 1990.
7. Niimi S, Nakagawa K, Yokota J, Tsunokawa $Y$, Nishio K, Terashima Y, Shibuya M, Terada M and Saijo N, Resistance to anticancer drugs in NIH-3T3 cells transfected with c-myc and/or c-H-ras genes. Br J Cancer 63: 237-241, 1991.

8. Burt RK, Garfield S, Johnson K and Thorgeirsson SS, Transformation of rat liver epithelial cells with $\mathrm{v}$-H-ras or $\mathrm{v}$-raf causes expression of MDR-1, glutathione-S-transferase-P and increased resistance to cytotoxic chemicals. Carcinogenesis 9: 2329-2332, 1988.

9. Sakai N, Ogiso Y, Fujita H, Watari H, Koike T and Kuzumaki $\mathrm{N}$, Induction of apoptosis by a dominant negative H-RAS mutant (116Y) in K562 cells. Exp Cell Res 215: 131-136, 1994.

10. Blenis J, Signal transduction via the MAP kinases: Proceed at your own RSK. Proc Natl Acad Sci USA 90: 5889-5892, 1993.

11. Marshall MS, The effector interactions of $\mathrm{p} 21^{\text {ras }}$. Trends Biochem Sci 18: 250-254, 1993.

12. Mar J, Forging a path to the nucleus. Science 260: 1588-1590, 1993.

13. Avruch J, Zhang X-F, and Kyriakis JM, Raf meets Ras: Completing the framework of a signal transduction pathway. Trends Biochem Sci 19: 279-283, 1994.

14. Mordret G, MAP kinase kinase: A node connecting multiple pathways. Biol Cell 79: 193-207, 1993.

15. Mansour SJ, Matten WT, Hermann AS, Candia JM, Rong S, Fukasawa K, Vande Woude GF, and Ahn NG, Transformation of mammalian cells by constitutively active MAP kinase kinase. Science 265: 966-970, 1994.

16. Nakagawa K, Saijo N, Tsuchida S, Sakai M, Tsunokawa $Y$, Yokota J, Muramatsu M, Sato K, Terada M and Tew KD, Glutathione-S-transferase $\pi$ as a determinant of drug resistance in transfectant cell lines. J Biol Chem 265: 4296-4301, 1990.

17. Kuo M-L, and Yang N-C, Reversion of v-H-ras-transformed $\mathrm{NIH} 3 \mathrm{~T} 3$ cells by apigenin through inhibiting mitogen activated protein kinase and its downstream oncogenes. Biochem Biophys Res Commun 212: 767-775, 1995.

18. Tsujimoto Y, Finger LR, Yunis J, Nowell PC and Croce CM, Cloning of the chromosome breakpoint of neoplastic B cells with the $t(14 ; 18)$ chromosome translocation. Science 226: 1097-1099, 1984.

19. Caron-Leslie L-AM, Evans RB and Cidlowski JA, Bcl-2 inhibits glucocorticoid-induced apoptosis but only partially blocks calcium ionophore or cycloheximide-regulated apoptosis in S49 cells. FASEB J 8: 639-645, 1994.

20. Jacobson MD, Burne JF, King MP, Miyashita T, Reed JC and Raff MC, Bcl-2 blocks apoptosis in cells lacking mitochondrial DNA. Nature 361: 365-369, 1993.

21. Rodriguez-Viciana P, Warne PH, Dhand R, Vanhaesebroeck B, Gout I, Fry MJ, Waterfield MD and Downward J, Phosphatidylinositol-3- $\mathrm{OH}$ kinase as a direct target of RAS. $\mathrm{Na}$ ture 370: 527-532, 1994.

22. Liscovitch $M$ and Cantley LC, Lipid second messengers. Cell 77: 329-334, 1994.

23. Vojtek AB, Hollenberg SM and Copper JA, Mammalian Ras interacts directly with the serine/threonine kinase Raf. Cell 74: 205-214, 1993.

24. Arrick BA and Nathan CF, Glutathione metabolism as a determinant of therapeutic efficacy: A review. Cancer Res 44: 4224-4232, 1984.

25. Armstrong DK, Gordon GB, Hilton J, Streeper RT, Colvin $\mathrm{OM}$ and Davidson NE, Programmed cell death in an estrogen-independent human breast cancer cell line, MDA-MB468. Cancer Res 52: 1416-1421, 1992.

26. Sklar MD, The ras oncogenes increase the intrinsic resistance of NIH 3T3 cells to ionizing radiation. Science 239: 645-647, 1988.

27. Sentman CL, Shutter JR, Hockenbery D, Kanagawa $O$ 
and Korsmeyer SJ, bcl-2 Inhibits multiple forms of apoptosis but not negative selection in thymocytes. Cell 67: 879-898, 1991.

28. Allsopp TE, Wyatt S, Paterson HF and Davies AM, The proto-oncogene bcl-2 can selectively rescue neurotrophic factor-dependent neurons from apoptosis. Cell 73: 295-307, 1993.

29. Fisher TC, Milner AE, Gregory CD, Jackman AL, Wynne Aherne G, Hartley JA, Dive C and Hickman JA, bcl-2 Modulation of apoptosis induced by anticancer drugs: Resistance to thymidylate stress is independent of classical resistance pathways. Cancer Res 53: 3321-3326, 1993.

30. Kinoshita T, Yokota T, Arai KI and Miyajima A, Regulation of Bcl-2 expression by oncogenic Ras protein in hematopoietic cells. Oncogene 10: 2207-2212, 1995.

31. Fairbairn LJ, Cowling GJ, Dexter TM, Rafferty JA and Margison GP, Bcl-2 delay of alkylating agent-induced apoptosis death in murine hemopoietic stem cell line. Mol Carcinogenesis 11: 49-55, 1994.

32. Lowe SW, Schmitt EM, Smith SW, Osborne BA and Jacks T, p53 is required for radiation-induced apoptosis in mouse thymocytes. Nature 362: 847-849, 1993.

33. Clarke AR, Purdie CA, Harrison DJ, Morris RG, Bird CC, Hooper ML and Wyllie AH, Thymocyte apoptosis induced by p53-dependent and independent pathways. Nature 362: 849 $852,1993$. 